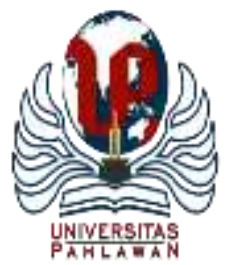

Edukatif : Jurnal Ilmu Pendidikan Volume 3 Nomor 5 Tahun 2021 Halm 3308 - 3317

EDUKATIF: JURNAL ILMU PENDIDIKAN

Research \& Learning in Education

https://edukatif.org/index.php/edukatif/index

\title{
Analisis Tindak Tutur Ilokusi dalam Proses Tawar Menawar dan Pemanfaatannya sebagai Bahan Ajar Teks Negosiasi di Sekolah Menengah Atas
}

\section{Aliza Zahra ${ }^{1 凶}$, Wienike Dinar Pratiwi ${ }^{2}$, Een Nurhasanah ${ }^{3}$}

Universitas Singaperbangsa Karawang, Indonesia ${ }^{1,2,3}$

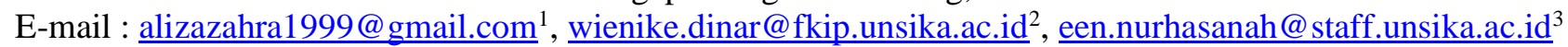

\begin{abstract}
Abstrak
Tujuan penelitian ini untuk mendeskripsikan bentuk tindak tutur ilokusi dan fungsi tindak tutur ilokusi dalam proses tawar menawar serta implementasinya sebagai bahan ajar teks negosiasi kelas X SMA. Metode yang digunakan adalah deskriptif kualitatif. Sumber data dalam penelitian ini adalah tindak tutur masyarakat Desa Cicinde Utara, Banyusari, Karawang. Kemudian pada tahap pengumpulan data menggunakan teknik observasi. Dalam teknik analisis data menggunakan reduksi data, penyajian data, penyimpulan dan verifikasi, kesimpulan akhir. Dengan begitu hasil akhir dalam penelitian ini menghasilkan 3 jenis tindak tutur ilokusi yang diantaranya : tindak tutur direktif 40 tuturan, tindak tutur asertif 3 tuturan, dan tindak tutur ekspresif 2 tuturan. Selanjutnya berdasarkan hasil penelitian ini akan dijadikan sebagai rekomdasi bahan ajar materi teks negosiasi kelas X SMA yang sudah melakukan validasi.
\end{abstract}

Kata Kunci : Pragmatik, Tindak Tutur, Teks Negosiasi.

Abstract

The purpose of this study is to describe the from of illocutionary speech acts and the funvtion of illo cutionary speech acts in the bargaining proces and their implementation as teaching. The source of data in this study is the speech acts of the people of North Cicinde Village, Banyusari, Karawang. Then at the data collection stage using observastion techniquues. In the data abnalysis technique data reduction, data presentation, conclusions and levers, final conclusions. Thus, the final result in this study resulted in 3 types off illocutoinary speech acts which include: 40 speech directive speech acts, 3 speech assertive speech acts, and 2 speech expressive speech acts. Furthermore, based on the results of this study, it will be used as a recommendation for teaching materials for negotiating texts for class X SMA that have been validated.

Keyboard: Pragmatics, Speech Acts, Negotiation Texts.

Copyright (c) 2021 Aliza Zahra, Wienike Dinar Pratiwi, Een Nurhasanah

$\triangle$ Corresponding author

Email : alizazahra1999@gmail.com

DOI : https://doi.org/10.31004/edukatif.v3i5.1278

ISSN 2656-8063 (Media Cetak)

ISSN 2656-8071 (Media Online) 
3309 Analisis Tindak Tutur Ilokusi dalam Proses Tawar Menawar dan Pemanfaatannya sebagai Bahan Ajar Teks Negosiasi di Sekolah Menengah Atas - Aliza Zahra, Wienike Dinar Pratiwi, Een Nurhasanah

DOI: https://doi.org/10.31004/edukatif.v3i5.1278

\section{PENDAHULUAN}

Di dalam ilmu linguistik yang mengkaji kebahasaan yang berdasarkan konteks adalah pragmatik. Adapun pendapat Yule (Yule, 2006) mengatakan bahwa pragmatik adalah studi tentang makna yang disampaikan oleh penutur (oleh penulis) dan di tafsirkan oleh pendengar (atau pembaca). Adapun menurut pendapat Rohmadi (Rohmadi, 2017) menjelaskan bahwa kajian pragmatik tidak dapat terlepas dari konteks tuturan. Pragmatik merupakan suatu ilmu yang mempelajari struktur bahasa yang digunakan dalam berkomunikasi. Selaras dengan pendapat Leech (Rohmadi, 2017) yang mengemukakan bahwa pragmatik mempelajari bagaimana bahasa digunakan dalam komunikasi, dan bagaimana pragmatik menyelidiki makna sebagai konteks, bukan sebagai sesuatu yang abstrak dalam komunikasi. Adapun pendapat ahli lain menurut Wijana, (Wijana, 1996) menjelaskan bahwa pragmatik adalah cabang ilmu bahasa yang mempelajari struktur bahasa secara eksternal, yakni bagaimana penggunaan satuan kebahasaan itu digunakan dalam komunikasi. Selain itu menurut Gunawan (Rohmadi, 2017) menjelaskan bahwa pragmatik selain untuk menyampaikan amanat, tugas, dan kebutuhan penutur, tujuan komunikasi adalah menjaga atau memelihara hubungan sosial penutur dengan pendengar. Dengan kata lain pragmatik merupakan telaah mengenai makna suatu ujaran sesuai dengan konteks dan situasi ujaran serta berfungsi sebagai bidang ilmu yang dapat menyampaikan pesan penutur kepada lawan tutur.

Di dalam prosesnya terdapat suatu peristiwa tutur. Peristiwa tindak tutur merupakan bentuk yang menjadi dasar bagi kegiatan komunikasi. Menurut Chaer dan Leonie Agustine (Purba, 2011) mengemukakan bahwa yang dimaksud dengan peristiwa tutur (speech event) adalah terjadinya atau berlangsungnya interaksi linguistik dalam satu bentuk ujaran atau lebih yang melibatkan dua pihak yakni penutur dan lawan tutur, dengan satu pokok tuturan dalam waktu, tempat, dan situasi tententu, jadi interaksi yang berlangsung antara seorang yang dapat disebut peristiwa tutur. Peristiwa tutur merupakan terjadinya suatu interaksi yang melibatkan dua pihak antara penutur dan mitra tutur yang bertujuan unuk melihat suatu makna dan tujuan pada tuturan tersebut.

Di dalam peristiwa tutur terdapat suatu bentuk ujaran yang disebut tindak tutur yang digunakan oleh penutur dan mitra tutur. Menurut Yule (Yule, 2006) mendefinisikan tindak tutur "as the action perfomedby a speaker with an utterance" yang diterjemahkan sebagai berkut : sebagai tindakan yang dilakukan oleh penutur dengan sebuah tuturan. Adapun pendapat lain menurut Chaer (Rohmadi, 2017) yang menyebutkan bahwa tindak tutur (speech act) adalah gejala indvindu yang bersifat psikologis dan keberlangsungannya ditentukan oleh kemampuan bahasa si penutur dalam menghadapi situasi tertentu. Jadi tindak tutur dapat dikatakan sebagai bentuk ujaran dalam berinteraksi. Selain itu Richard (Purba, 2011) mengemukakan bahwa tindak tutur (dalam arti yang sempit sekarang) adalah peristiwa minimal dari pemakaian situasi tutur/peristiwa tutur/tindak tutur.

Tindak tutur memiliki beberapa jenis yang dikemukakan oleh Searle (Wibowo, 2018) yang menyatakan bahwa ada 3 jenis tindakan yang dapat diwujudkan oleh seorang penutur, yakni tindak lokusi (locutionary act), tindak ilokusi (ilocuttionary act), dan tindak perlokusi (perlocutionary). Menurut Wijana, (Wijana, 1996) menjelaskan tindak tutur lokusi adalah tindak tutur untuk menyatakan sesuatu. Tindak tutur ilokusi bermaksud semata-mata untuk memberikan suatu informasi untuk melakukan sesuatu, dan mampu mempengaruhi lawan bicaranya. Tindak tutur ilokusi digunakan dalam sebuah tuturan untuk melakukan sesuatu. Menurut Wijana, (Wibowo, 2018) tindak tutur ilokusi yaitu tindak tutur yang mengandung maksud yang berkaitan dengan siapa bertutur kepada siapa, kapan, dan dimana tindak tutur itu dilakukan. Selaras dengan pendapat Putrayasa (Sagita \& Setiawan, 2020) bahwa tindak tutur ilokusi merupakan apa yang ingin kita dicapai oleh penuturnya pada saat menuturkan sesuatu dan dapat merupakan tindakan menyatakan, berjanji, meminta maaf, mengancam, meramalkan, memerintah, meminta, dan lain sebagainya. Selain itu menurut Yule (Meirisa et al., 2017) mengemukakan bahwa tindak ilokusi ditampilkan melalui penekanan komunikatif sebuah ujaran. Jadi 

Negosiasi di Sekolah Menengah Atas - Aliza Zahra, Wienike Dinar Pratiwi, Een Nurhasanah

tindak tutur ilokusi adalah suatu bentuk ujaran yang bersifat pada maksud dari tuturan untuk dilakukan oleh mitra tutur sesuai ujaran penutur. Selanjutnya mengenai klasifikasi tindak tutur menurut Yule, (Yule, 2006) mencantumkan 5 jenis fungsi umum yang ditunjukan oleh tindak tutur; deklarasi, representatif, ekspresif, direktif, dan komisif. Dan terakhir ada tindak tutur perlokusi yang diartikan sebuah tuturan yang digunakan dalam sebuah komunikasi yang seringkali mempunyai daya pengaruh atau bisa disebut dengan perlocutionary force. Menurut Wijana, (Wijana, 1996) tindak tutur perlokusi adalah tindak tutur yang pengaturannya dimaksud untuk memengaruhi lawan bicara. Jenis tindak tutur ini dapat menimbulkan pengaruh secara disengaja atau tidak di senagaja yang dikreasikan oleh penuturnya.

Tindak tutur dan peristiwa tutur ini menjadi dua gejala yang terdapat pada satu proses, yakni proses komunikasi, Chaer (Wibowo, 2018). Adapun pendapat lain menurut Hymes (Wibowo, 2018) mendeskripsikan sebuah teori yang di dalamnya terkandung unsur-unsur konteks tindak tutur. Peristiwa tutur juga dapat dikatakan sebagai kegiatan interaksi sosial antara penutur dengan mitra tutur dengan menggunakan bahasa secara konvesional untuk mencapai suatu hasil yang akan dicapai. Unsur tersebut diakronimkan dengan S.P.E.A.K.I.N.G.

Konteks dalam pragmatik dapat diartikan sebagai bagian yang tidak dapat dipisahkan dengan "ujaran" yang bisa berwujud kalimat maupun uraian yang dapat memperkuat kejelasan suatu makna situasi yang berkaitan dengan proses kejadian. Menurut Wibowo (Wibowo, 2018) menyebutkan bahwa Konteks adalah lingkungan di sekitar tuturan yang memungkinkan peserta tutur untuk berinteraksi dalam peristiwa komunikasi dan membuat bentuk kebahasaan yang digunakan dalam interaksi itu dapat dimengerti.

Dalam suatu komunikasi memiliki maksud dan tujuan yang berbeda-beda, dapat dilihat bagaimana seseorang menyampaikan suatu pemikiran melalui ujaran dengan cara berpikiran jernih sehingga tidak mengeluarkan sesuatu perkataan yang dapat menyinggung lawan bicara. Dalam berinteraksi juga perlu adanya arahan serta aturan agar terciptanya suatu komunikasi yang baik dan susuai kaidah yang berlaku. Salah satunya dengan cara memahami bagaimana fungsi serta makna setiap perkataan yang di ujarkan, serta dapat mengarahkan sesuai dengan maksud tujuan yang diujarakan. Hal ini harus diperhatikan karena dapat menciptakan suatu keindahan atau seni dalam berbahasa, jika seseorang telah memahami bagaimana berbahasa dengan baik dalam berkomunikasi dengan begitu dapat dikatakan bahwa ia telah melakukan komunikasi secara optimal.

Namun, realitanya yang sering terjadi di kehidupan sekitar mengenai negosiasi. Masih banyak kalangan masyarakat yang belum memperhatikan serta mempertimbangkan dalam bertutur maka dari itu berkaitan dengan fenomena tersebut berkaitan dengan kajian pragmatik yang membahas mengenai penuturan makna yang dilakukan oleh penutur dan mitra tutur dengan dipengaruhi situasi tutur. Maka dari itu hal ini akan dijelaskan secara rinci bagimana penggunaan bahasa yang digunakan oleh masyarakat Desa Cicinde Utara dalam proses tawar menawar dengan menggunakan pendekatan pragmatik yang memfokuskan pada analisis tindak tutur ilokusi.

Hal itu berkaitan dengan peristiwa yang kerap kali ditemui oleh peneliti pada saat interaksi sosial dengan masyarakat dalam proses tawar-menawar di Desa Cicinde Utara, Banyusari, Karawang untuk melakukan bernegosiasi dalam konteks jual-beli pakaian terbukti bahwa masyarakat setempat mengutarakan keinginan untuk menurunkan harga barang yang berlebihan serta mengingikan barang yang sesuai pembeli dengan harga yang murah dan kualitas yang bagus serta masyarakat tidak memahami etika berbahasa dalam bernegosiasi. Berdasarkan latar belakang masalah yang telah diuraikan diatas maka tujuan penelitian tersebut untuk mendreskripsikan wujud tindak tutur ilokusi, fungsi tindak tutur lokusi, dan hasil analisis tindak tutur direktif dalam proses tawar menawar di Desa Cicinde Utara, Banyusari, Karawang.

Berdasarkan hasil penelitian direkomendasikan sebagai bahan ajar materi teks negosiasi di kelas $\mathrm{X}$ SMA yang telah dilakukan validasi. Menurut Widodo dan Jasmadi (Ahmad, 2010) menyatakan bahwa bahan ajar adalah seperangkat sarana atau alat pembelajaran yang berisikan materi pembelajaran, metode, dalam 

Negosiasi di Sekolah Menengah Atas - Aliza Zahra, Wienike Dinar Pratiwi, Een Nurhasanah

DOI: https://doi.org/10.31004/edukatif.v3i5.1278

rangka mencapai tujuan yang diharapkan, yaitu mencapai kompetensi atau subkompetensi dengan segala kompleksitas. Menurut Pannen (Magdalena et al., 2020) bahwa bahan ajar adalah bahan atau materi pembelajaran yang disusun secara sistematis yang digunakan guru dan siswa dalam proses pembelajaran. Adapun menurut Sudrajat (Ahmad, 2010) berpendapat bahan ajar adalah seperangkat materi yang disusun secara sistematis baik tertulis maupun tidak sehingga tercipta lingkungan/suasana yang memungkinkan siswa untuk belajar. Selain itu pendapat lain mengenai bahan ajar menurut Sofan dan Lif (Legendari \& Raharjo, 2016) mengatakan bahwa bahan ajar adalah segala bentuk bahan yang digunakan untuk membantu guru/instruktur dalam melaksanakan kegiatan belajar mengajar di kelas. Bahan ajar atau materi pelajaran yang akan diberikan kepada mampu memperhatikan serta mempertimbangkan karakteristik peserta didik. Seperti yang kemukakan oleh Ahmad Kasani (Ahmad, 2010) bahan ajar atau modul memiliki beberapa karakteristik, yaitu self instructional, self contained, stand alone, adaptive dan user friendly. Dan menurut pendapat Robbins (Utami, 2017) menjelaskan bahwa negosiasi adalah sebuah proses dimana dua pihak atau lebih melakukan pertukaran barang atau jasa dan berupaya untuk menyepakati nilai tukarnya. Bentuk bahan ajar menurut Prastowo (Magdalena et al., 2020) dari segi bentuknya menyebutkan bahwa bahan ajar dapat dibedakan menjadi empat macam, yaitu: bahan ajar cetak, audio, audio visual, interakstif, Jadi bahan ajar adalah seperangkat alat yang digunakan oleh para tenaga pendidik untuk melakukan suatu pengajaran dengan berisikan materi-materi kepada peserta didik. Bahan ajar ini bisa membantu para tenaga didik dalam memberikan suatu ilmu kepada peserta didik seperti pendapat Prastowo (Kusumam et al., 2016) maaf tersebut dibedakan menjadi dua yaitu manfaat bagi guru dan siswa.

Teks negosiasi merupakan suatu kegiatan interaksi sosial yang melibatkan kedua belah pihak atau pihak-pihak yang berkaitan untuk memecahkan keputusan akhir dari sebuah perbedaan pendapat. Kegiatan bernegosiasi sering kita jumpai dimana-mana seperti kegiatan interaksi sosial di pasar antara penjual dengan pembeli untuk melakukan sebuah transaksi jual beli untuk menemukan kesepakatan antara penjual dengan pembeli. Istanjo (Aulia et al., 2017) berpendapat bahwa negosiasi merupakan suatu proses yang melibatkan sedikitnya dua pihak dan setiap pihak melihat pihak lain memiliki suatu yang dibutuhkannya. Adapun menurut ahli lain, Dawson (Hasnah \& Jupfri, 2015) berpendapat bahwa negosiasi dapat dilakukan secara lisan dan tulisan. Selain itu Menurut Phil Baguley (Utami, 2017) menyebutkan bahwa negosiasi adalah suatu cara untuk menetapkan keputusan yang dapat disepakati dan diterima oleh dua pihak dan menyetujui apa dan bagaimana tindakan yang akan dilakukan di masa datang. Dan menurut pendapat Robbins (Utami, 2017) menjelaskan bahwa negosiasi adalah sebuah proses dimana dua pihak atau lebih melakukan pertukaran barang atau jasa dan berupaya untuk menyepakati nilai tukarnya. Dengan begitu negosiasi dapat dimaknai sebagai bentuk usaha yang bertjuan untuk menyelesaikan segala bentuk berbedaan serta hal-hal yang bertentangan diantara pihak-pihak yang berkepentingan untuk mencari jalan keluar.

Adapun penelitian yang terkait dengan penelitian ini adalah penelitian dari Veranita Ragil Sagita dengan judul penelitian "Tindak Tutur Ilokusi Ridwan Kamil dalam Talkshow Insight di CNN Indonesia" Terdapat perbedaan diantaranya objek yang dikaji yang mana pada penelitian Veranita menggunakan Objek tuturan Ridwan Kamil sedangkan Penelitian ini adalah tuturan masyarakat Desa Cicinde Utara. Kemudian perbedaan lainnya seperti teknik pengumpulan data pada penelitian Veranita menggunakan metode pengumpulan data teknik simak bebas libat cakap danteknik catat artinya peneliti tidak langsung berinteraksi dengan subjek yang dituju sedangkan penelitian ini menggunakan teknik penggumpulan data melalui rekaman dan berinteraksi langsung dengan subjek yang dituju karena peneliti menjadi penjual yang terlibat langsung dengan masyarakat Desa Cicinde Utara untuk melakukan proses tawar menawar. Dan teknik analisis yang digunakan pun berbeda yaitu pada penelitia Veranita menggunakan metode padan pragmatik dan metode agih, sedangkan penelitian ini menggunakan teknik analisis reduksi data, penyajian data, penyimpulan data serta verifikasi dan kesimpulan akhir. 
3312 Analisis Tindak Tutur Ilokusi dalam Proses Tawar Menawar dan Pemanfaatannya sebagai Bahan Ajar Teks Negosiasi di Sekolah Menengah Atas - Aliza Zahra, Wienike Dinar Pratiwi, Een Nurhasanah

DOI: https://doi.org/10.31004/edukatif.v3i5.1278

\section{METODE PENELITIAN}

Metode penelitian adalah langkah untuk menemukan hasil melalui penelitian. Menurut Sugiono (Sugiono, 2018) mengatakan bahwa metode penelitian adalah metode penelitian yang berlandaskan pada filsafah postpositivisme, digunakan untuk meneliti pada kondisi yang alamiah, (sebagai lawannya adalah eksperimen) dimana peneliti adalah sebagai instrumen kunci, teknik pengumpulan data dilakukan secara triangulasi (gabungan), analisis data bersifat induktif/deduktif, dan hasil penelitian kualitatif lebih menekankan makna dari pada generalisasi. Penelitian ini adalah penelitian kualitatif dengan metode deskriptif. Karena hasil dalam penelitian ini adalah berupa deskripsi mengenai tuturan lisan masyarakat pada saat proses tawar menawar. Menurut Bogdan dan Taylor (Sujarweni, 2020) menjelaskan bahwa penelitian kualitatif adalah salah satu prosedur penelitian yang mengasilkan data deskriptif berupa ucapan atau tulisan dan perilaku orang-orang yang diamati. Objek penelitian ini berupa bahasa lisan atau tuturan. Kemudian subjek dalam penelitian ini adalah masyarakat Desa Cicinde Utara, Banyusari, Karawang.

Instrumen penelitian menurut Sugiyono (Sugiono, 2018) berpendapat bahwa instrumen adalah suatu alat yang digunakan mengukur fenomena alam maupun sosial yang diamati. Pada penelitian ini yang menjadi isntrumen adalah peneliti itu sendiri karena peneliti berperan sebagai keseluruhan dalam mengumpulkan data dengan berpedoman kepada aspek analisis. Pada saat pengumpulan data menggunakan teknik observasi partisipatif yang dibantu dengan handphone dengan teknik sadap untuk merekam situasi yang terjadi di lapangan dengan beberapa tahap yang diantaranya: tahap awal, inti dan penutup. Peneliti akan mengambil 10 data dari ujaran lisan dalam transaksi jual beli yang mana peneliti berperan sebagai penjual pakaian dan masyarakat setempat berperan sebagai pembeli atau konsumen. Menurut Mudjiarahardjo (Sugiono, 2018) menyebutkan bahwa analisis data adalah sebuah kegiatan untuk mengatur, mengurutkan, mengelompokkan, memberi kode atau tanda dan, mengkategorikannya sehingga diperoleh suatu temuan berdasarkan fokus atau masalah yang ingin di jawab. Dari data tersebutlah peneliti menganalisis tindak tutur ilokusi dengan menggunakan reduksi data, penyajian data, penyimpulan dan verifikasi, keimpulan akhir. Dalam prosesnya peneliti berinteraksi langsung dengan subjek karena peneliti berperan sebagai pejual pakaian dan masyarakat Desa Cicinde sebagai konsumen atau pembeli. Untuk waktu yang dibutuhkan dalam penelitain membutuhkan 4 bulan mulai dari bulan Maret, April, Mei, dan Bulan Juni.

\section{HASIL DAN PEMBAHASAN PENELITIAN}

Berkaitan dengan data yang di dapatkan dalam penelitian ini menghasilkan 3 jenis tindak tutur ilokusi yang diantaranya: tindak tutur direktif sebanyak 40 tuturan yang diantaranya 16 tindak tutur direktif menyarankan, 4 tindak tutur direktif melarang, 8 tindak tutur direktif memerintah dan 12 tindak tutur direktif mengkritik. Tindak tutur sertif sebanyak 3 tuturan diantaranya menceritakan 2 tuturan, dan menyakinkan 1 tuturan. Dan tindak tutur ekspresif sebanyak 2 tuturan diantaranya memuji 2 tuturan. Yang akan dijelaskan sebagai berikut.

\section{Data Tindak Tutur Ilokusi}

Tindak tutur ilokusi digunakan dalam sebuah tuturan untuk melakukan sesuatu. Menurut Wijana, (Wibowo, 2018) tindak tutur ilokusi yaitu tindak tutur yang mengandung maksud yang berkaitan dengan siapa bertutur kepada siapa, kapan, dan dimana tindak tutur itu dilakukan. Berdasarkan hasil penelitian terdapat 3 jenis tindak tutur ilokusi, diantaranya tindak tutur direktif, tindak tutur asertif, dan tindak tutur ekspresif. Yang di jelaskan sebagai berikut : 
3313 Analisis Tindak Tutur Ilokusi dalam Proses Tawar Menawar dan Pemanfaatannya sebagai Bahan Ajar Teks Negosiasi di Sekolah Menengah Atas - Aliza Zahra, Wienike Dinar Pratiwi, Een Nurhasanah

DOI: https://doi.org/10.31004/edukatif.v3i5.1278

\section{Tindak Tutur Direktif}

Tindak tutur direktif merupakan bagian jenis tindak tutur ilokusi yang memiliki fungsi untuk mempengaruhi lawan bicara untuk melakukan sesuatu sesuai yang diutarakan penutur. Selaras dengan pendapat Wibowo (Wijana, 1996) menyatakan bahwa tindak tutur direktif merupakan tuturan yang diujarkan oleh penutur dengan maksud agar mitra tutur berkenaan melakukan tindakan yang sesuai dengan apa yang dituturkan. Dalam penelitian ini terdapat tindak tutur menyarankan, melarang, memerintah, dan mengkritik, yang dijelaskan sebagai berikut :

a. Tindak Tutur Direktif Menyarankan

Tindak tutur menyarankan adalah jenis tindak tutur yang makna ilokusinya memberikan sebuah saran atau memberikan suatu anjuran kepada lawan tutur. Tuturan yang bermaksud menyarankan yang ditemukan sebanyak 16 tuturan. Sebagai contoh tuturan menyarankan sebagai berikut :

Keterangan : Peneliti berperan sebagai penjual dan masyarakat Desa Cicinde Utara sebagai pembeli Konteks tuturan : dalam percakapan ini dilakukan oleh Salwa berusia 17 tahun pada hari minggu, 20 Juli 2021 pukul 16:00 WIB. Pada percakapan tersebut menunjukan Salwa sedang mengutarakan sebuah tuturan yang bersifat memberikan saran kepada penjual. Dan tidak membeli pakaian yang ditawarkan oleh penjual.

\section{Bentuk tuturan :}

Pembeli : "Tapi tong mahal-mahal nya, Teh".

"Tapi jangan mahal-mahal yah, Teh".

Penjual : "Nya tos kalem ka Awa mah, komo k tatangga mh gampang".

"Ya sudah santai ke Awa mah, apalagi ke tetanggan mah gampang".

Fungsi tuturan : Bertujuan untuk memberi saran kepada penjual agar tidak memberikan harga pakaian yang terlalu tinggi, kalimat tersebut dapat dibuktikan dengan kata "tapi" yang artinya pembeli ingin membeli sebuah produk yang ditawarkan dengan catatan tidak memberikan harga yang terlalu tinggi. Dengan begitu kalimat tersebut termasuk jenis tindak tutur "Menyarankan".

b. Tindak Tutur Direktif Melarang

Tindak tutur direktif melarang merupakan suatu tindakan yang memiliki tujuan untuk memperingatkan kepada lawan tutur untuk tindakan melakukan sesuatu atau memperbolehkan kepada lawan tutur. Tuturan yang bermaksud melarang yang ditemukan sebanyak 4 tuturan. Sebagai contoh tuturan melarang sebagai berikut :

Keterangan : Peneliti berperan sebagai penjual dan masyarakat Desa Cicinde Utara sebagai pembeli.

Konteks tuturan : dalam percakapan ini dilakukan oleh Anita berusia 22 tahun pada hari Minggu, 22 Mei 2021 pukul 15:00 WIB. Pada percakapan tersebut menunjukan bahwa Anita sedang mengutarakan sebuah tuturan yang bersifat melarang kepada penjual agar tidak mengambil keuntungan yang terlalu tinggi. Pembeli membeli sebuah pakaian tunik wanita berbahan plisket.

\section{Bentuk tuturan :}

Pembeli : "Euntong seueur teuing nyandak batina".

"Jangan terlalu banyak ambil untungnya".

Penjual : "Heunteu, entos hargi pas".

"Enggak, sudah harga pas".

Fungsi tuturan : Pada tuturan tersebut bertujuan agar penjual tidak mengambil keuntungan yang terlalu besar. Yang dapat ditandai penggunaan kata "Euntong" yang berasal dari bahasa sunda yang memiliki arti "jangan" Dengan demikian kalimat tersebut termasuk ke dalam tindak tutur "Melarang". c. Tindak Tutur Direktif Memerintah 
3314 Analisis Tindak Tutur Ilokusi dalam Proses Tawar Menawar dan Pemanfaatannya sebagai Bahan Ajar Teks Negosiasi di Sekolah Menengah Atas - Aliza Zahra, Wienike Dinar Pratiwi, Een Nurhasanah

DOI: https://doi.org/10.31004/edukatif.v3i5.1278

Tindak tutur direktif memerintah adalah tindak tutur yang makna ilokusi bermasuk untuk memberikan suruhan kepada lawan tutur. Tuturan yang bermaksud memerintah yang ditemukan sebanyak 8 tuturan. Sebagai contoh tuturan memerintah sebagai berikut :

Keterangan : Peneliti berperan sebagai penjual dan masyarakat Desa Cicinde Utara sebagai pembeli.

Konteks tuturan : pada percakapan ini dilakukan oleh Ibu Ema berusia 35 Tahun pada hari Minggu, 13 Juni 2021, pukul 15:30 WIB. Pada percakapan tersebut Ibu Ema mengutarakan sebuah tuturan yang bersifat suruhan untuk dibawakan sebuah celana laki-laki kepada penjual. Di samping itu Ibu Ema membeli sebuah pakaian tunik berbahan katun rayon.

\section{Bentuk tuturan :}

Pembeli : "Cik mawakeun calana lalaki atuh".

"Cik bawain celana laki-laki dong".

Penjual : "Naon? nu Hidnu? Hayu".

"Apa? Yang Hidnu? Hayu".

Fungsi tuturan : Yang berarti mengutarakan sebuah perintah agar penjual melakukan hal yang diminta oleh pembeli dengan cara membawakan sebuah celana yang dibuktikan dengan kata "bawakeun" yang memiliki arti bawain, secara tidak langsung tuturan tersebut mengandungsiatu makna memerintah kepada penjual. Dengan demikian kalimat tersebut termasuk ke dalam tindak tutur "Memerintah".

d. Tindak Tutur Direktif Mengkritik

Tindak tutur direktif mengkritik adalah tindak tutur yang bertujuan untuk mengemukakan kritikan seperti memberikan tanggapan atau kecaman kepada lawan tutur. Tuturan yang bermaksud mengkritik yang ditemukan sebanyak 12 tuturan. Sebagai contoh tuturan mengkritik sebagai berikut : Keterangan : Peneliti berperan sebagai penjual dan masyarakat Desa Cicinde Utara sebagai pembeli. Konteks tuturan : pada percakapan ini dilakukan oleh Ibu Erni berusia 40 Tahun pada hari Minggu, 13 Juni 2021, pukul 15:30 WIB. Pada percakapan tersebut Ibu Erni mengutarakan sebuah tuturan yang bersifat kritikan terhadap pakaian yang dibawakan oleh pnjual. Di samping itu Ibu Ema membeli sebuah pakaian tunik berbahan katun rayon.

\section{Bentuk tuturan :}

Penjual : "Saetik deui teh hayu, Tah ieu acuk rajut teh".

"Sedikit lagi kak ayo, nah ini baju rajut kak".

Pembeli : "Kos nu panas bahan rajut kieu teh".

"Sepertinya panas bahan nya".

"Apa? Buat Hidnu? Boleh".

Fungsi tuturan : Tuturan tersebut memiliki maksud serta tujuan untuk menyampaikan sebuah kritikan pada pakaian dengan bahan rajut yang terasa panas jika dipakai, dapat dibuktikan dengan kalimat "kos nu panas bahan rajut teh". Dengan begitu ujaran tersebut dapat dikatakan sebagai fungsi tindak tutur direktif "Mengkritik".

\section{Tindak Tutur Asertif}

Tindak tutur asertif melibatkan pembicara pada kebenaran proposisi yang diekspresikan, misalnya: menyatakan, memberitahukan, menyarankan, membanggakan, mengeluh, menunut, melaporkan. Ilokusi aseftif bersifat netral dari segi kesopanannya. Berdasarkan hasil penelitian menemukan tindak tutur asertif sebagai berikut :

1. Tindak Tutur Asertif Meyakinkan

Tindak tutur asertif menyakinkan sebuah tuturan yang bersifat memastikan. Menurut Wibowo (Wibowo, 2018) menyebutkan bahwa tindak tutur asertif merupakan salah satu ragam tindak tutur 
3315 Analisis Tindak Tutur Ilokusi dalam Proses Tawar Menawar dan Pemanfaatannya sebagai Bahan Ajar Teks Negosiasi di Sekolah Menengah Atas - Aliza Zahra, Wienike Dinar Pratiwi, Een Nurhasanah

DOI: https://doi.org/10.31004/edukatif.v3i5.1278

asertif yang proposisi ilokusi tuturannya berupaya dengan sungguh-sungguh untuk membuat mitra tuturnya percaya atas kebenaran suatu hal yang disampaikan penutur. Berdasarkan data yang diperoleh pada tindak tutur tutur asertif meyakinkan terdapat 1 tuturan, sebagai berikut :

Konteks tuturan : Percakapan transaksi tawar menawar yang dilakukan oleh Ibu Piah berusia 52 Tahun, pada hari Minggu, 12 Mei 2021, pukul 15:20 WIB, yang bertempat di rumah, dengan jenis pembelian pakaian koko laki-laki dewasa.

Keterangan : Peneliti berperan sebagai penjual dan masyarakat desa Cicinde Utara sebagai pembeli.

\section{Bentuk tuturan :}

Pembeli : "Bener yeuh teu di pasihan Rp.300.000,00"

"Bener nih tidak di kasih Rp.300.000,00"

Fungsi tuturan : Tuturan tersebut memiliki maksud serta tujuan untuk menyampaikan sesuatu yang bersifat kepastian mengenai disetujui atau tidak kegiatan negosiasi yang membahas mengenai penawaran harga sebuah barang, yang dapat dibuktikan dengan kalimat "Bener yeuh teu di pasihan Rp.300.000”. Kalimat tersebut memiliki makna seperti ungkapan benar tidak di kasih kalau dengan harga Rp.300.000; yang ditunjukan melakukan negoiasi kepada penjual. Dengan begituu ujaran tersebut dapat dikatakan sebagai fungsi tindak tutur asertif "Meyakinkan".

2. Tindak Tutur Asertif Menceritakan

Tindak tutur asertif menceritakan bersifat memberikan suatu informasi. Menurut Wibowo (Wibowo, 2018) menyebutkan bahwa tindak tutur asertif menceritakan adalah salah satu jenis tindak tutur asertif yang maksud tuturannya berupaya membentang bagaimana terjadinya suatu hal (peristiwa, kejadian, dan sebagainya). Berdasarkan data yang diperoleh pada tindak tutur asertif menceritakan terdapat 2 tuturan. Berikut ini adalah contoh tindak tutur asertif menceritakan:

Konteks tuturan : Percakapan transaksi tawar menawar yang dilakukan oleh Ibu Dewi berusia 32 Tahun, pada hari Minggu, 13 Juni 2021, pukul 17:00 WIB, yang bertempat di rumah, dengan jenis pembelian tidak membeli suatu produk yang ditawarkan oleh penjual.

Keterangan : Peneliti berperan sebagai penjual dan masyarakat desa Cicinde Utara sebagai pembeli.

\section{Bentuk tuturan :}

Pembeli : "Keur ieu mah masih ku emih haji nagihan na baju teh sok ical wae"

"Waktu itu masih sama nenek haji nagihin nya baju tuh suka ilang mulu"

Fungsi tuturan : Tuturan tersebut memiliki maksud serta tujuan untuk menyampaikan sesuatu atau informasi kepada penjual mengenai pengelaman yang ia alami, yang dapat dibuktikan dengan kalimat "Keur ieu mah masih ku emih haji nagihan na baju teh sok ical wae". Dengan begitu ujaran tersebut dapat dikatakan sebagai fungsi tindak tutur asertif "Menceritakan".

\section{Tindak Tutur Ekspresif}

Tindak tutur ekspresif mempunyai fungsi untuk mengekspresikan, mengungkapkan atau memberitahukan sikap psikologis sang pembicara menuju suatu pernyataan keadaan yang diperkirakan oleh ilokusi. Pada data yang diperoleh terdapat 2 tuturan yang menunjukkan tindak tutur asertif memuji. Dan berikut adalah contoh tindak tutur asertif :

1. Tindak Tutur Ekspresif Memuji 

Negosiasi di Sekolah Menengah Atas - Aliza Zahra, Wienike Dinar Pratiwi, Een Nurhasanah

DOI: https://doi.org/10.31004/edukatif.v3i5.1278

Konteks tuturan : Percakapan transaksi tawar menawar yang dilakukan oleh Ibu Ade berusia 30 Tahun, pada hari Minggu, 28 Maret 2021, pukul 15:20 WIB, yang bertempat di rumah, dengan jenis pembelian tidak membeli suatu produk yang ditawarkan oleh penjual.

Keterangan : Peneliti berperan sebagai penjual dan masyarakat desa Cicinde Utara sebagai pembeli.

\section{Bentuk tuturan :}

Pembeli : "Atos jatuh cinta ieu oge ka bajuna."

"Udah jatuh cinta ini juga sama bajunya."

Fungsi tuturan : Tuturan tersebut memiliki maksud serta tujuan untuk menyampaikan sesuatu bersifat pujian kepda penjual mengenai pakaian yang dibawakan oleh penjual, yang dapat dibuktikan dengan kalimat "Atos jatuh cinta ieu oge ka bajuna". Kalimat tersebut diakatan sebagai tindak tutur asertif karena pengucapan kalimat "jatuh cinta" kepada penjual sebagai bentuk pujian atas suatu barang yang dibawakan oleh penjual. Dengan begitu ujaran tersebut dapat dikatakan sebagai fungsi tindak tutur ekspresif "Memuji".

Berdasarkan hasil penelitian sebelumnya mendapatkan hasil analisis yang menunjukan adanya bentuk dan jenis tidak tutur ilokusi dalam talkshow di CNN Indonesia yang terdapat 90 tuturan yang meliputi: pertama, bentuk tindak tutur ilokusi terdapat tiga bentuk yaitu deklaratif, introgatif, dan imperatif. Kedua, jenis tindak tutur ilokusi terdapat empat jenis yaitu asertif, direktif, komisif. Dan ekspresif. Bentuk deklaratif terdapat 68 tuturan sedangkan bentuk introgatif terdapat 14 tuturan, dan imperatif terdapat 8 tuturan. Sementara itu, dari jenisnya terdapat 54 tuturan berjenis asertif, 18 tuturan berjenis direktif, 7 tuturan berenis komisif, dan 11 tuturan berjenis ekspresif.

\section{KESIMPULAN}

Dari hasil penelitian ini mengenai bentuk tindak tutur ilokusi dan fungsi tindak tutur ilokusi menunjukan bahwa penggunaan bahasa yang digunakan oleh masyarakat pada saat proses tawar menawar memiliki tujuan serta maksud untuk menyatakan keinginan pembeli yang lebih di dominasi dalam menurunkan harga sebuah produk yang ditawarkan oleh penjual, sehingga pada saat proses tawar menawar berlangsung masyarakat tidak banyak yang memahami bagaimana penyampaian bertutur yang baik pada saat bernegosiasi. Berdasarkan hasil akhir dalam penelitian ini menghasilkan 3 jenis tindak tutur ilokusi yang diantaranya : tindak tutur direktif 40 tuturan, tindak tutur asertif 3 tuturan, dan tindak tutur ekspresif 2 tuturan. Selanjutnya berdasarkan hasil penelitian ini akan dijadikan sebagai rekomendasi sebagai bahan ajar materi teks negosiasi kelas X SMA yang sudah melakukan validasi.

\section{UCAPAN TERIMA KASIH}

Penulis mengucapkan terima kasih yang sedalam-dalamnya kepada pihak-pihak yang terlibat dalam penelitian ini atas bimbingan Ibu Wienike Dinar Pratiwi, S.Pd., M.Pd., sebagai dosen penguji 1 dan Ibu Dr. Een Nurhasanah, SS., MA., sebagai pembimbing 2. Dan tak lupa saya ucapkan kepada kedua orang tua saya yang senatiasa mengorbankan pikiran, dorongan serta do'a yang dipanjatkan setiap hari guna kelancaran saya dalam pembuatan penlitian ini. Dan pihak-pihak lain yang tidak bisa dijelaskan melalui kata-kata.

\section{DAFTAR PUSTAKA}

Ahmad, K. I. L. (2010). Pengembangan Bahan Ajar Perkembangan Anak Usia Sd Sebagai Sarana Belajar Mandiri Mahasiswa Kasina Ahmad Ika Lestari. Perspektif Ilmu Pendidikan, 22(8), 183-193. 
3317 Analisis Tindak Tutur Ilokusi dalam Proses Tawar Menawar dan Pemanfaatannya sebagai Bahan Ajar Teks Negosiasi di Sekolah Menengah Atas - Aliza Zahra, Wienike Dinar Pratiwi, Een Nurhasanah DOI: https://doi.org/10.31004/edukatif.v3i5.1278

Aulia, Rizki, C., \& Haryadi. (2017). Peningkatan Keterampilan Memproduksi Teks Negosiasi Lisan Menggunakan Metode Pasar Kelas Dengan Meda Audio Visual Pada Peserta Didik Kelas X Social Science-2 Sma Negeri 3 Slawi. Jurnal Pendidikan Bahasa Dan Sastra Indonesia, 6, 27-33.

Hasnah, S., \& Jupfri. (2015). Pembelajaran Menulis Teks Negosiasi Melalui Model Pembelajaran Berbasis Masalah Di Sma. Jurnal Penelitian Pendidikan Insani, 18(1), 50-57.

Kusumam, A., Mukhidin, M., \& Hasan, B. (2016). Pengembangan Bahan Ajar Mata Pelajaran Dasar Dan Pengukuran Listrik Untuk Sekolah Menengah Kejuruan. Jurnal Pendidikan Teknologi Dan Kejuruan, 23(1), 28. Https://Doi.Org/10.21831/Jptk.V23i1.9352

Legendari, M. A., \& Raharjo, H. (2016). Pengembangan Bahan Ajar Berbasis Audio Visual Terhadap Hasil Belajar Siswa Pada Materi Pokok Bangun Ruang Kubus Dan Balok Kelas Viii Di Smp N 1 Ciledug. Eduma: Mathematics Education Learning And Teaching, 5(1). Https://Doi.Org/10.24235/Eduma.V5i1.683

Magdalena, I., Sundari, T., Nurkamilah, S., Nasrullah, \& Amalia, D. A. (2020). Analisis Bahan Ajar. Nusantara: Jurnal Pendidikan Dan Ilmu Sosial, 2(2), 311-326. Https://Ejournal.Stitpn.Ac.Id/Index.Php/Nusantara

Meirisa, M., Rasyid, Y., \& Murtadho, F. (2017). Tindak Tutur Ilokusi Dalam Interaksi Pembelajaran Bahasa Indonesia (Kajian Etnografi Komunikasi Di Sma Ehipassiko School Bsd). Bahtera: Jurnal Pendidikan Bahasa Dan Sastra, 16(2), 1-14. Https://Doi.Org/10.21009/Bahtera.162.01

Purba, A. (2011). Tindak Tutur Dan Peristiwa Tutur. Pena, Volume 1, 77-91.

Rohmadi. (2017). Pragmatik Teori Dan Analisis. Yuma Pustaka.

Sagita, V. R., \& Setiawan, T. (2020). Tindak Tutur Ilokusi Ridwan Kamil Dalam "Talkshow Insight" Di Cnn Indonesia (The Form And Type Of Illocutionary Speech Acts Ridwan Kamil In The "Insight Talkshow" At Cnn Indonesia). Lensa: Kajian Kebahasaan, Kesusastraan, Dan Budaya, 9(2), 187. Https://Doi.Org/10.26714/Lensa.9.2.2019.187-200

Sugiono. (2018). Metode Penelitian, Kuantitatif, Kualitatif Dan R\&D. Alfabeta Cv.

Sujarweni, V. W. (2020). Metode Penelitian. Pustakabarupress.

Utami, F. I. D. (2017). Efektivitas Komunikasi Negosiasi Dalam Bisnis. Komunike, Ix(2), 105-122.

Wibowo, S. E. (2018). Etnopgragmatik Bingkai Budaya Kiai Jawa. Cv. Sarnu Untung.

Wijana, D. P. I. (1996). Dasar-Dasar Pragmatik. Andi.

Yule, G. (2006). Pragmatik. Pustaka Belajar. 